\title{
PEMENUHAN HAK ASASI PADA SAAT PANDEMI COVID
}

\author{
Alfina Rusliana, Anita Trisiana, Aida Rahmawati Dwi Kencana \\ Jl. Sumpah pemuda No.18, kadipiro, kec. Banjarmasi, Kota Surakarta, Jawa Tengah 57136
}

Arus72614@gmail.com

\begin{abstract}
Abstrak
Pada masa pandemic seperti ini Indonesia sebagai Negara yang demokrasi ydan mementingkan rakyatnya harus dapat memastikan bala rakyat nya dalam keadaan baik - baik saja dimasa yang sulit ini. Pemenuhan kebutuhan seperti kebutuhan ekonomi, dan kebutuhan yang mungkin sulit didapatkan pada masa pandemic seperti ini perlu menjadi perhatian pemerintah. Banyak hal yang harus dipenuhi di masa pandemi seperti ini terutama yang bersangkutan dengan hak - hak warga Negara Indonesia. Pemerintah harus berupaya memenuhi segala hak yang harusnya diperoleh oleh warganya namun hilang dimasa pandemic seperti ini. Seperti tujuan penulisan jurnal ini, yang kami tulis untuk melihat dan menganalisis bagaimana cara kerja pemerintah dalam mengayomi masyarakat dan melindungi masyarakat sesuai dengan ketentuan UUD. Hak asasi sendiri merupakan seperangkat hak yang dari kita hidup ( lahir ) bahkan dari kita di dalam kandungan sudah diberikan tuhan yang maha esa. Hal ini pun tah luput dari UU yang ada di Indonesia yang juga ikut melindungi hak asasi manusia terutama warga Indonesia. UU juga mengatur bagaimana cara pemerintah dalam memberikan dan melindungi hak asasi manusia kepada warganya. Hak asasi manusia memiliki pengaruh yang sangat besar Berpengaruh besar terhadap perekonomian yang ada di Indonesia. Salah satunya banyaknya pengangguran karena di masa pandemic ini perusahaan banyak yang mem-phk para karyawannya. jika tidak melakukan phk maka perusahaan akan mengalami kebangkrutan. Pandemic covid dampaknya bukan hanya banyaknya pengangguran saja tetapi ke siswa/siswi dan mahasiswa karena harus belajar online. Hak asasi manusia yang harus di peroleh pada saat pandemic covid ialah hak yang berkaitan atas dasar kesehatan, hak dasar informasi yang harusnya diperoleh masyarakat, hak tentang atas dasar privasi, hak tentang pekerjaan dan beberapa hak lainnya yang harus didapatkan masyarakat terutama pada masa pandemmi seperti ini. Pada saat pandemic ini pemerintah juga telah banyak melakukan upaya seperti memberikan bantuan sembako. Pererintah juga serig melakukan razia protocol kesehatan dan memberi denda yang melanggar protocol kesehatan agar masyrakat jera.
\end{abstract}

Kata Kunci : Hak Asasi Manusia, Masa Pandemi 


\begin{abstract}
During a pandemic like this, Indonesia as a country that is democratic and concerned with its people must be able to ensure that its people are in good condition during this difficult time. Fulfilling needs such as economic needs and needs that may be difficult to obtain during a pandemic like this needs to be paid attention by the government. Many things must be fulfilled during a pandemic like this, especially with regard to the rights of Indonesian citizens. The government must try to fulfill all the rights that should be obtained by its citizens but are lost in a pandemic like this. Like the purpose of writing this journal, which we write to see and analyze how the government works in protecting the community and protecting the community in accordance with the provisions of the Constitution. Human rights themselves are a set of rights from which we live (are born) and even those of us in the womb have been given one and only God. Until we arrive at him a set of rights inherent in the nature and existence of humans as creatures of God Almighty and are His gifts that must be respected, upheld and protected by the rule of law, the Government, and everyone for the honor and protection of human dignity. Human rights have a very big influence. They have a big influence on the economy in Indonesia. One of them is the large number of unemployed people because during this pandemic many companies have laid off their employees. if they do not lay off, the company will go bankrupt. The Covid pandemic has an impact not only on unemployment but also for students and students because they have to study online. Human rights that must be obtained during the Covid pandemic are rights related to health, basic information rights that should be obtained by the community, rights on the basis of privacy, rights regarding work and several other rights that must be obtained by the community, especially during a pandemic like this. . During this pandemic the government has also made many efforts, such as providing basic food assistance. The government also carries out raids on health protocols and provides fines that violate health protocols so that the public is deterred.
\end{abstract}

Key word : $\quad$ Human right, during a pandemi 


\section{PENDAHULUAN}

Virus yang dinamakan Covid - 19 atau yang biasanya diebut dengan virus corona merupakan panyakit yang sangat cepat menular dan semakin tingginya pasien positif corona maka berakibat sangat nyata seperti banyaknya perusahaan yang mem-phk(putusan hubungan kerja). Hal ini terjadi dikarenakan banyak sector yang rugi karena adanya pandemic seperti ini. Keberlangsungan dunia usaha yang berpengaruh pada dunia ketenagakerjaan yang tidak stabil sehingga terjadinya pengangguran dan banyak hak-hak masyarakat yang tidak dapat di penuhi. Wabah Corona virus yang muncul ternyata menjadi wabah yang sangat besar dan sangat mempengaruhi Indonesia dalam sector perekonomian hal yang sama pun bahkan juga terjadi di seluruh dunia yang perekonomiannya juga memburuk bahkan lembaga keuangan dunia seperti Dana Moneter Internasional (IMF) memperkirakan ekonomi global akan tumbuh pada angka - 3\%. Dampak Covid-19 terhadap perekonomian yang berada di Indonesia ternyata memiliki banyak dampak yang cukup signifikan. Akibat munculnya wabah ini pemerintah mencatat melalui Kementrian keuangan dan jajarannya apabila wabah ini membuat setidaknya delapan dampak utama wabah dari covid - 19 terhadap system ekonomi di Indonesia. Mulai dari angkatan kerja hingga kinerja . berikut beberapa dampak dari covid - 19 terhadap perekonomian yang ada di Indonesia :

\section{PHK ekstensif}

Kementerian Keuangan menunjukkan bahwa pandemi Covid-19 telah menyebabkan penderitaan yang meluas bagi pekerja formal dan informaldustri Tanah Air. Dampak ini sangat merusak tatanan sosial dan ekonomi Indonesia. Sedikitnya 1,5 juta pekerja di-PHK dan terkena dampak PHK. 90\% dari mereka ditembakkan dan 10\% sisanya ditembakkan. Sebanyak 1,24 juta pekerja formal dan 265.000 pekerja informal.

\section{Kontraksi PMI manufaktur}

Industri manufaktur PMI secara umum menunjukkan kinerja industri pengolahan dalam negeri baik dari segi produksi, permintaan baru dan jumlah penyerapan tenaga kerja yang besar, sehingga berdampak besar pada industri manufaktur khususnya terhadap tenaga kerja. Kementerian Keuangan mencontohkan, industri manufaktur PMI Indonesia mengalami kontraksi yang dalam hingga 45,3\%, atau lebih rendah dari angka pada Agustus 2019 (yang saat itu masih 49).

\section{Dampak terhadap kinerja impor}

Sejak tampilan terakhir, kinerja impor juga mengalami penurunan yang sangat tajam, hingga triwulan I tahun 2020 telah turun sebesar 3,7\% year-to-date (ytd).

\section{Dampak terhadap inflasi}

Kementerian Keuangan menunjukkan bahwa hingga Maret 2020, tingkat inflasi domestik meningkat $2,96 \%$ tahun-ke-tahun. Inflasi disebabkan oleh harga emas perhiasan dan beberapa jenis makanan.

5. Pembatalan total seluruh penerbangan baik domestik mapun penerbangan internasional

Kementerian Perhubungan mencontohkan, Covid-19 telah turut mengganggu industri penerbangan. Antara Januari hingga Maret 2020, setidaknya 12.703 penerbangan di 15 bandara di Indonesia dibatalkan.Informasi detail penerbangan domestik 11.680, dan detail informasi penerbangan internasional adalah 1.073 kelas.

\section{Penurunan jumlah wisatawan asing}

Jumlah kunjungan wisatawan mancanegara (wisman) berdampak signifikan terhadap perekonomian domestik, dan Covid19 berdampak besar, serta wisman yang tidak dibatasi telah mengurangi lebih dari 7.000 wisman setiap harinya. Kunjungan wisatawan mancanegara biasanya terutama wisatawan mancanegara dari China.

7. Hilangnya pendapatan dari jasa
penerbangan
$\begin{gathered}\text { Pembatalan } \\ \text { penerbangan }\end{gathered}$
pengurangan turis asing tentu saja akan


berdampak pada kerugian harian lebih dari 300 miliar rupiah pendapatan industri jasa penerbangan.

\section{Mengurangi masa inap hotel}

Karena dampak dari covid - 19 ini juga berdampak pada hal pariwisata, hal ini juga merugikan para pengusaha yang bergerak dibidang perhotelan. Tidak adanya wisatawan yang berkunjung akan mengakibatkan hotel sepi dan tidah adanya pemasukan untuk hotel maupun tempat penginapan. Dari cststsn dan penelitian yang dilakukan kementrian Kepariwisataan, dalam masa pandemic ini Indonesia kehilangan sumber tersebesar devisanya yaitu dalam bidang pariwisata. Hal ini akan berdampak pada laku atau tidaknya keinapan di hotel. Kementrian kepariwisataan pun juga mencatat jika lebih dari 60 ribu hotel yang ada di Indonesia kehilangan lebih dari 50 $\%$ pengunjungnya. Bahkan ada beberapa hotel yang terpaksa tutup karena sama sekali tidak ada pengunjung.

\section{METODE PENELITIAN}

Saat merancang jurnal, metode yang digunakan adalah penelitian yang bersifat kualitatif dan deskriptif. Cara kualitatif dalam meneliti jurnal adalah metode penelitian deskriptif dan analitik dengan menonjolkan hasil penelitian dalam prosesnya. Terkait dengan landasan teori yang digunakan adalah kesadaran subyektif peneliti. Cara ini sering juga disebut dengan metode naturalistic karena biasanya ditulis dalam kondisi penulisan subjek.

Meskipun metode penelitian deskriptif digunakan untuk mendeskripsikan fenomena yang masih berjalan. Karena itulah penulis pun memilih menggunakan cara ini, karena saat ini pandemi Covid-19 masih ada dan masih mewabah ke masyarakat. Kami memilih diskusi ini karena pandemi Covid-19 masih berdampak besar pada gaya hidup masyarakat. Semua aspek kehidupan tidak berjalan dengan baik.

Selama pandemi Covid-19, fungsi abnormal pada aspek-aspek kehidupan tertentu menjadi alasan utama hilangnya hak asasi manusia tertentu di masyarakat. Selama pandemi ini, berbagai masalah yang berkaitan dengan kehidupan mereka terancam. Khawatir tentang bagaimana kehidupan mereka bekerja, mengkhawatirkan virus corona yang mematikan, bahkan kehilangan pekerjaan adalah masalah serius bagi kelangsungan hidup mereka. Oleh karena itu, pemerintah sedang berupaya untuk segera menyelesaikan pandemi ini. Tidak hanya pemerintah, masyarakat juga telah bekerja sama untuk memerangi pandemi ini.

\section{RUMUSAN MASALAH DAN PEMBAHASAN}

A. Rumusan Masalah

1. Apa yang harus diketahui tentang hak yang harus didapatkan manusia atau HAM ?

2. Apa pengaruh covid terhadap hak asasi manusia?

3. Apa saja hak yang harus di peroleh masyarakat pada saat pandemi covid terjadi?

4. Bagaimana peran dan upaya pemerintah dalam menangani covid ?

5. Bagaimana cara pemertintah dalam mengangani banyaknya karyawan yang terkena phk dimasa pandemic covid 19 ?

6. Apa saja peran yang harus dilakukan oleh masyarakat dalam membantu menangani kasus pandemic covid 19 ini?

B. Pembahasan

\section{Pengertian hak asasi manusia}

HAM atau hak asasi manusia adalah suatu hak yang sejak lahir diberikan oleh Tuhan yang maha esa keapa setiap pribadi . HAM di Indonesia sendiri juga diatur dalam UU RI no 39 yang berisi bahwa HAM adalah seperangkat hak yang diberikan oleh tuhan kepada setiap manusia sejak dirinya ada, maka Negara wajib melindungi hak - hak setiap warganya dan harus menjunjung tinggi seluruh HAM yang dimiliki seluruh warganya. Menjaga dan melindungi HAM sesorang bukan hanya kewajiban Negara, namun kita sesame makhluk 
sosial memiliki kewajiban yang sama dalam melindungi HAM diri ita sendiri ataupun orang lain. Kita harus mampu melindungui kehormatan dan harga diri setiap makhluk sosial.

Dalam pancasila yang merupakan idiologi Negara Indonesia juga mengatur tentang HAM dimana pancasila membebaskan seluruh warga untuk memeluk agama sesuai keyakinannya masing - masing, masyarakat juga berhak melakukan musyawarah untuk mufakat serta hak masyarakat untuk mendapat perlindungan dari pemerintah. Ham dapat mencakup hak pribadi, termasuk kebebasan berbicara, kebebasan beragama, dan kebebasan bergerak.Seluruh manusia sebagai makhluk ciptaan tuhan yang maha esa perlu menjunjung tinggi hak asasi mereka. mereka berhak melindungi harga diri, harkat dan martabat yang harus dijunjung tinggi, kebebasan dan keamanan dalam kehidupan serta hak untuk hidup tanpa ancaman dari orang lain. Hak asasi manusia mempromosikan rasa saling menghormati di antara manusia. Kita harus mampu mejaga Hak asasi dengan penuh tanggung jawab dan kesadaran, agar tindakan kita dalam menjaga hak asasi tidak pada jalan yang salah dan dapat melindungi hak asasi tanpa merusak hak asasi orang lain. Hak asasi manusia memiliki ciri-ciri sebagai berikut: makna yang melekat adalah bahwa hak asasi manusia adalah manusia sejak lahir; makna universal bahwa hak asasi manusia berlaku untuk setiap orang, tanpa memandang ras, kepercayaan, ras, atau suku (etnis), dan tidak dapat dicabut yang berarti hak asasi manusia tidak dapat ditaati Yang lainnya tidak dapat dipisahkan, artinya setiap orang berhak menikmati semua hak, baik hak sipil maupun politik, atau hak ekonomi, sosial, dan budaya. Setelah memenuhi Hak asasi manusia memiliki dua arti yaitu (1) Hak asasi manusia merupakan hak alamiah yang melekat dalam diri setiap manusia sejak ia lahir ke dunia. Hak alam/ hak alamiah adalah hak yang sesuai dengan manusia sebagai, melindungi dan menghormati hak asasi manusia, kewajiban manusia (KAM) dan tanggung jawab manusia (TAM) harus dipenuhi. Hak asasi manusia memiliki dua arti yaitu (1) Hak asasi manusia merupakan hak alamiah yang melekat dalam diri setiap manusia sejak ia lahir ke dunia. Hak alam/ hak alamiah adalah hak yang sesuai dengan manusia sebagai kebebasan, kecerdasan, dan hakikat manusia. Tidak seorang pun diizinkan untuk mendapatkan hak ini dari pemiliknya. Ini tidak berarti bahwa hak asasi manusia adalah hak mutlak yang tidak dibatasi, karena pembatasan hak asasi manusia yang dimiliki seseorang merupakan hak asasi manusia yang melekat pada orang lain. Jika hak asasi manusia dirampas dari setiap orang, maka kemanusiaan akan kehilangan eksistensinya sebagai manusia. (2) Hak asasi manusia adalah sarana atau alat untuk melindungi harkat dan martabat manusia. Tanpa hak asasi manusia, manusia tidak akan bisa hidup sesuai dengan martabat sebagai pribadi ketuhanan yang paling sempurna. Hak asasi manusia memiliki enam jenis, yaitu hak pribadi, hak politik, persamaan hak hukum, hak ekonomi, dan hak prosedural. Ada beberapa undang-undang tentang hak asasi manusia, misalnya Pasal 28A mengatur tentang hak untuk hidup, Pasal 28B mengatur tentang hak untuk berkeluarga, Pasal 28C mengatur tentang hak atas pendidikan, dan Pasal 28D mengatur tentang kebebasan beragama.

Hak asasi manusia bukan lagi sekedar perwujudan individualisme dan liberalisme. Dalam pengertian hak asasi manusia, hak asasi manusia adalah hak yang melekat pada martabat manusia, tanpa membedakan ras, ras, 
agama, warna kulit, jenis kelamin, dan pekerjaan.

Pemerintah memiliki tanggung jawab terbesar untuk melindungi dan memajukan hak asasi manusia. Selain pemerintah, masyarakat yang juga harus berperan aktif dalam penghormatan dan perlindungan HAM adalah masyarakat.

Hak asasi manusia berasal dari gagasan utama dalam Alkitab, yang menunjukkan bahwa manusia diciptakan oleh Tuhan dan memiliki hak dan kewajiban yang sama. Tuhan melarang perlakuan sewenang-wenang terhadap manusia. Tuhan tidak membedakan warna kulit dan kaya atau miskin.

\section{Pengaruh Covid terhadap hak asasi manusia}

Covid adalah peristiwa luar biasa yang sangat mempengaruhi semua bidang kehidupan di dunia saat ini. Akibat pandemi Covid-19, banyak hal yang mengubah tatanannya. Peran COVID-19 sangat kentara di semua sektor kehidupan, salah satunya adalah sektor ekonomi. Di bidang ekonomi, akibat banyaknya perusahaan yang diberhentikan, telah terjadi pengangguran baru. Banyak krisis yang terjadi di suatu negara. Hal ini berdampak pada perekonomian suatu negara. Banyak faktor yang menyebabkan terjadinya pelanggaran HAM. Misalnya tidak adanya kebijakan perlindungan HAM. Prinsip, hukum dan institusi HAM tidak efektif dalam memperhatikan HAM. Dalam pandemi seperti itu, setiap orang akan menjadi egois sehingga dapat hidup dalam masa sulit ini tanpa memikirkan nasib orang lain. Akan banyak terjadi pelanggaran HAM di masyarakat, seperti pencurian, penculikan, kejahatan dan kejahatan lainnya yang akan menimbulkan ketidaknyamanan atau bahkan kerusuhan di masyarakat. Belakangan ini, beberapa petugas kesehatan di rumah sakit bahkan melakukan beberapa tindak pidana, seperti mencuri beberapa jenis alat kesehatan yang sulit dibeli di Indonesia, seperti masker dan hand sanitizer, karena harga yang berlaku saat ini memang tinggi. Efek covid terlihat jelas di lingkungan sekitarnya. Semua orang berlomba-lomba menghentikan penyebaran virus ini karena pandemi tersebut telah membuat dunia kacau.

Selama pandemi ini, hak asasi yang dipegang oleh masyarakat sangat terganggu. Masyarakat yang semestinya merasa nyaman, aman dan terlindungi oleh pemerintah dalam pandemi ini justru merasa cemas. Bisa jadi karena kebijakan pemerintah yang longgar, munculnya berbagai kejahatan di lingkungan sekitar, ancaman pengangguran, dan ancaman virus Covid-19 itu sendiri yang mungkin ada di sekitar kita. Orang-orang merasa gelisah dan gelisah dalam wabah ini. Misi pemerintah adalah melindungi dan memberikan perlindungan kepada masyarakat melalui peralatan ini agar masyarakat merasa nyaman, aman, tentram dan betah selama terjadinya pandemi ini.

\section{Hak-hak yang harus diperoleh selama wabah Covid}

Dalam pandemi ini, masyarakat harus memenuhi haknya, seperti hak untuk mengetahui informasi dan edukasi terkait virus corona, termasuk pencegahan dan pengendalian. Masyarakat juga perlu mendapat pendidikan dari pemerintah secara rutin, karena tingkat pendidikan di masyarakat berbeda-beda.Beberapa masyarakat segera mengetahui bahwa sebagian masyarakat memerlukan pendidikan ulang agar memahami dan mengambil tindakan yang tepat, serta berhak memenuhi kebutuhan dasar makan sehari-hari. Permintaan, seperti pasokan sembako di pasar. . Dalam pandemi seperti ini, hak-hak masyarakat tersebut merupakan hak 
yang paling penting untuk kelangsungan hidup mereka. Ini termasuk semua hak yang harus diperoleh orang selama pandemi ini antara lain :

- Hak atas kesehatan

Kesehatan masyarakat penting untuk menjalankan aktivitas seharihari. Selama pandemi ini masyarakat sangat prihatin karena ancaman penyakit dapat menyebar kepada kita kapanpun dan dimanapun. Kualitas pelayanan kesehatan terkait COVID-19 merekomendasikan rumah sakit untuk menangani COVID-19. Berbagai rumah sakit rujukan COVID-19 mengalami banyak kendala, seperti minimnya akses informasi, minimnya tenaga medis, minimnya sarana dan prasarana penunjang pelayanan kesehatan, serta minimnya prosedur khusus untuk pemeriksaan pasien COVID-19. Pada saat yang sama, karena pembatasan operasi dan akses, komunitas masih memiliki sedikit layanan pengujian PCR. Oleh karena itu, tugas pemerintah adalah menyediakan rumah sakit, khususnya rumah sakit rujukan Covid-19, dengan segera peralatan, sarana dan prasarana yang lengkap. Pasien yang ingin menjalani pemeriksaan kesehatan untuk virus covid -19 .

Akses ke perawatan medis merupakan bagian integral dari seluruh hak asasi manusia. Prinsip yang mendasar pada pemenuhan hak atas kesehatan saat ini. Negara harus memperhatikan kesediaan, aksesibilitas, penerimaan dan kualitas pelayanan kesehatan yang diberikan ke masyarakat. Pekerjaan yang pemrosesan negara sanagat minim telah menyebabkan penyebaran COVID-19 di komunitas, dan jumlah penyebaran dan pemrosesan tidak terkendali

- Hak atas informasi

Update terbaru tentang covid-19 di Indonesia sangat penting bagi masyarakat. Dalam menangani suatu pandemi, harus efektif, andal, dan senantiasa diperbarui dengan informasi tentang situasi pandemi dan penanganannya, informasi tersebut harus disadari dan tersedia untuk umum tanpa terkecuali. Ketika gejala muncul atau dipastikan positif Covid, tindakan tindak lanjut yang harus dilakukan masyarakat juga harus diinformasikan kepada publik. Hal ini sangat penting karena tidak adanya obat atau vaksin untuk menanggulangi virus ini, keselamatan warga sangat bergantung pada informasi tentang pencegahan dan pengendalian perilaku individu yang harus dilakukan masyarakat pada saat-saat seperti itu. Namun, di awal penyebaran COVID19, karena jika pihak berwenang menutup dan menolak memberikan informasi, sebenarnya hal itu salah mengirimkan sinyal dan instruksi kepada masyarakat sehingga mengurangi kewaspadaan yang dapat berakibat fatal dan memperparah penyebaran wabah tersebut. bencana. Banyak kasus yang merugikan kesehatan dan pelanggaran HAM akibat tidak terpenuhinya hak untuk mengetahui antara lain penggunaan desinfektan, obat-obatan dan suplemen yang tidak dianjurkan, praktik diskriminatif yang melanggar hak privasi, seperti menolak mengubur mayat yang terpapar COVID-19, dan menolak pasien. Orang yang menunjukkan gejala seperti covid-19 di rumah sakit rumah dan yang penduduknya menolak bekerja di institusi yang menghadapi orang dengan gejala Covid-19.

Hal ini melanggar kewajiban untuk mengkomunikasikan informasi dari berbagai regulasi. Pemerintah indonesia secara teratur menetapkan serta mengumumkan jenis dan penyebaran penyakit yang mungkin akan menular dan menyebar dalam waktu yang singkat. karena pada dasarnya menjamin semua manusia berhak mencari hak (jika hak yang 
seharusmya ia dapat tetapi tidak terpenuhi ) , memperoleh hak, memiliki hak, dan mengkomunikasikan.

- Hak atas dasar privasi

Pasien positif corona memiliki hak privasi, sehingga pasien positif corona tidak akan merasakan tekanan akibat banyaknya pemberitaan media oleh pejabat publik tentang tempat tinggalnya. Belum lagi dampak pemberitaan yang berdampak pada lingkungan sekitar, seperti keluarga, tetangga dan teman. Privasi akan sangat mempengaruhi masa pemulihan pasien. Mereka berhak merahasiakan identitasnya sebagai pasien positif corona dari publik. Ini akan membuat mereka dan keluarganya merasa nyaman. Oleh karena itu privasi pasien harus dijaga.

- Hak atas pekerjaan

Dengan berlakunya PSBB, kebijakan isolasi sosial dan kebijakan bekerja jauh dari rumah, pekerja dari rumah tangga formal hingga pekerja sektor informal, dari pekerja industri domestik hingga UMKM, semuanya rentan terhadap pemotongan upah, pencabutan hak cuti, kembali ke negara , dan mem-phk karyawannya. Jika setiap perusahaan memilih untuk mengurangi hari libur karyawan, maka pemerintah harus memastikan setiap perusahaan tetap membayarkan upah para karyawannya yang sesuai dengan UU 33 tahun 2016 (tentang hak untuk bekerja).

Hal ini menimbulkan kecemasan yang besar di masyarakat. Mereka dapat kehilangan pekerjaan kapan saja. Pengusaha memiliki ide yang sama, dan mereka juga memikirkan bagaimana bisnis mereka akan berlanjut. Mereka tidak hanya mempertimbangkan kelangsungan bisnis, tetapi juga nasib karyawan yang bekerja dengan mereka. Pandemi seperti itu sulit dilakukan secara normal. Untuk mengurangi risiko penyebaran virus dan mengurangi ruang gerak pekerja dan pengusaha, banyak peraturan dan harapan pemerintah telah dirumuskan.

\section{Upaya dan peran pemerintah dalam menangani pandemic covid - 19}

a.setelah mendengar kabar bahwa adanya penyakit virus corona pemerintah Indonesia sudah melakukan berbagai pencegahan agar virus coronatidak masuk ke negara Indonesia. Berikut adalah langkahlangkah pecegahannya :

- pemerintah indonesia melakukan penerbitkan surat edaran ke seluruh wilayah Indonesia mulai dariprovinsi, kabupaten / kota, kecamatan/desa, rumah sakit rujukan, rumah sakit umum/swasta, RT dan RWagar masyarakat dapat meningkatkan kewaspadaan dan mencegah kemungkinan penyakit ini masuk ke daerahnya masing-masing.

- 135 pemindai termal telah dipasang di semua bandara yang ada di Indonesia, terutama ada yang melakukan penerbangan langsung dari cina dan sekitar daerah yang dekat dengan negara cina.

- Memberi penumpang kartu peringatan kesehatan dan memberikan informasi tentang pecegahan covid-19 yaitu dengan melakukan protocol kesehatan.

- pemerintah memilih minimal 100 rumah sakit sebagai rumah sakit rujukan yang digunakan untuk sebagai tempat pasien yang positif corona. Pemerintah indonesia telah menyiapkan 21 butir kapsul untuk evakuasi (pendorongpasien yang melalukan isolasi) sebagai tindakan preventif.

- Pemerintah mengimbau orang-orang dari episentrum COVID-19 atau mereka yang melakukan perjalanan dari episentrum COVID-19 untuk menyadari bahwa mereka harus mengisolasi diri selama 14 hari, mengenakan masker dan menjaga jarak 
meskipun tidak ada gejala atau ketidaknyamanan.

-Pemerintah juga selalu mengingatkan masyarakat dengan menginformasikan atau mengedukasi melalui siaran TV, siaran radio, surat kabar bahwa harus selalu menggunakan $3 \mathrm{M}$ yaitu cuci tangan, pakai masker, jaga jarak.

b. Pemerintah Indonesia membuka layanan kontak yang dapat diakses olehseluruh masyarakat Indonesia agar mengetahui tentang seputar virus corona. Nomor layanan kontak yang dapat digunakan masyarakat untuk menghubungi pemerintah Indonesia yaitu 0215210411 dan +6281212123119.

c. Pada tanggal 2 Februari 2020, Pemerintah Indonesia memberikan informasi:

- bahwa di seluruh bandara yang ada di Indonesia semua penerbangan akan di tunda antara yang mau berpergerian ke luar atau yang ingin masuk ke Indonesia.

- Semua warga di larang untuk masuk ke indonesiadan transit di Indonesia. Jika waktu 14 hari yang terakhir ada di negara China.

- Dengan di cabutnya visa dan devisa untuk sementara yang kedatangan bagi mastarakat China.

- Pemberhentianimpor hewan hidup asal daerah China untuk sementara.

d. Pemerintah Indonesia telah melakukan pemulangan Warga Negara Indonesia sebagai bentuk perlindugan yang berasal dari daerah yaitu : Provinsi Hubei, cina. Yang saat itu tanggal 2 Februari 2020. Langkahlangkah berikut telah diterapkan kepada WNI tersebut:

- Pastikan adanya ketersediaan makanan dan bahanlogistic yang ada di daerah cina dan ada kebijakan karantina Pemerintah cina dan telah memberikan bantuan finansial ke warga negara indonesia yang mayoritasnya adalah pelajar agar terpenuhi kebutuhannya seperti makanan dan bahan logistic lainnya yang ada di daerah cina.

- Pengiriman bahan logistik dari negara Indonesia: dari Kementerian Luar Negeri indonesia dan pemerintah cina yang sudah memberikan masker sebanyak 10.000 kepada warga Negara indonesiayang ada di daerah China.

- Menjemput 237 semua warga kenergaraan indonesia dan 1 warga keneegaraan asing yang ada di Negara cina mulai tanggal 1 februari 2020 - 2 Februari 2020.

- Mulai 2 Februari 2020, semua warga kenegaraan Indonsesia yang bersama 5 tim adju dari Negara cina dan ada 42 orang tim evakuasi yang melakukan pemeriksaan kesehatan dalam waktu 14 hari yang ada di Pangkalan tentara Negara Indonesia angkatan udara Raden Sadjad yang ada di kepulau Natuna.

- Tanggal 15 Februari 2020, semua warga Negara Indonesia dan seluruh tim evakuasi yang telah selesai melakukan masa karantina dan dinyatakan sehat, (sembuh) dari virus corona.

e.Pada saat pandemic saat 39 ini pemerintah sering memberikan bantuan kepada masyarakat39 seperti sembako dan uang.

f.Pemerintah sering melakukan razia kepada seluruh masyarakat indonesia yang tidak pakai masker selama berada di luar rumah dan para pelanggar 39rotocol kesehatan akan di beri denda dan sanksi berupa membayar uang senilai Rp.100.000 - Rp.500.000 atau membersihkan taman jalan.

g.Pemerintah juga sering mengadakan rapid tes seoerti di pasar, di kedinasan dan lain sebagainya. Dengan melakukan rapid tes ini agar pemerintah mengetahui ada atau tidaknya pasien positif covid. 
h.Pemerintah selalu menginformasikan bahwa setiap ingin berpergian ke luar kota mengunakan jalur darat, laut maupun udara harus ada surat keterangan bebas covid 19 dari dokter.

i.Pemerintah setiap hari selalu mengupdate perkembangan pasien positif corna, pasien sembuh dan pasien yang meninggal dunia agar masyarakat dapat mengetahui perkembangan covid di Indonesia.

j.Selama pandemi pemerintah memberikan kuota gratis untuk belajar kepada para pelajar, mahasiswa, guru dan dosen.

\section{Cara pemertintah dalam mengangani banyaknya karyawan yang terkena phk dimasa pandemic covid - 19}

Pada pandemic seperti ini banyaknya orang-orang yang kena phk ( pemberhentian kontrak kerja ) seperti yang tercatat ada 162.416 karyawan terdampak. Dinas ketenagakerjaan, dinas Transmigrasi daerah Jakarta telah mencatat ada 162.416 pekerja/karyawan yang ada di Jakarta dan sudah dirumahkan tanpa di gaji karena pandemic virus corona. Rinciannya yaitu ada 30.137 karyawan dari 3.348 perusahaan yang merumahkan para karyawannya, sedangkan ada karyawan yang di rumahkan oleh perusahaan dan tanpa mendapatkan gaji. Akhirnya pemerintah menangani tentang banyaknya para pekerja yang di rumahkan yaitu dengan cara peluncuran program kartu prakerja. Salah satu bidang yang terkena phk adalah dari SPG ( sales promotoion gril ) hingga honorer. Para pekerja yang terkena dampak phk tersebut telah di rumahkan tanpa mendapatkan upah karena perusahaan tersebut juga tidak dapat pemasukan sehingga keryawan yang di phk tidak dapat gaji ( upah ). Rincian bantuan pemetintah dalam kartu prakerja yaitu dengan biaya bantuan untuk melakukan pelatihan sebesar $\mathrm{Rp} 1.000,000$, maka biayauntuk pelatihan sebesar Rp 600.000 setiap bulan dan selama 4 bulannya dan biaya insentif untuk survei ketenagakerjaan sebesar Rp 150.000. Setiap orang yang mengikuti program kartu prakerja yang dapat mengikuti program sebanyak satu kali dan akan dibayarkan setelah para peserta kartu prakerja menyelesaikan pelatihan minimal melakukan satu kali pelatihan. Pemerintah juga memberikan strategi, agar setiap perusahaan dapat menerapkan kebijakan guna menjaga stabilitas perusahaan. Karena kebijakan tersebut maka diharapkan semua perusahaan dapat bertahan dalam kondisi pandemic seperti ini. Pengusaha juga dapat membuat strategi dengan berfokus pada Surat Edaran Menteri Tenaga Kerja dan Transmigrasi bahwa agar semua perusahaan tetap bertahan dan menghindari Pemutusan hubungan kerja atau dirumahkan karyawan/pekerja. Langkah yang dapat diterapkan di semua perusahaan taitu dengan memotong gaji dan fasilitas karyawan di tingkat atas. Contohnya di tingkat manajer yaitu dapat mengurangi shift kerja,dihapuskannya kerja lembur, Mengurangi jam saat kerja, Meliburkan atau merumahkan pekerja/buruh/ karyawanyang secara bergulir untuk waktu yang sebentar. Di pecat atau di perpanjang kontraknya bagi karyawan yang sudah tidak ada lagi masa kontrak, Memberikan pensiunan untuk karyawan/pekerja yang sudah memenuhi persyaratan.

pemerintah harus fokus dan teliti untuk mengatasi pandemic virus corona dengan melakukan semua upaya untuk mencegah terjadinya para pekerja di rumahkan. Tidak efektif untuk mencegah terjadinya pemutusan hubungan kerja. jika hanya memberikan program kartu prkerja dan tips agar tidak mem-phk para karyawannya maka potensi orang-orang yang terkena pemutusan hubungan kerja jauh lebih besar dari quota kartu prakerja yang sudah tersedia. Jadi saat ini pemeritah harus melakukan langkahlangkah sebagai berikut :

- Melakukan penurunan biaya produksi perusahaan swasta, dengan cara meliburkan para karyawan tetapi harus tetap membayar upah penuh. Supaya produksi akan tetap berjalan dan bisa diatur skema libur yang bergilir. Jadi 
akan ada penghematan listrik, cettering.

- Pemerintah Indonesia melakukukan pengendalian kebijakan fiskal dan moneter supaya nilai tukar rupiah tidak akan melemah dan saham gabungan tidak akan turun drastis.

- Kalau masalah bahan baku yang tidak ada Negara pemasok karena negara pemasok sedang melakukan tindakan lockdown karena adanya virus corona maka Negara indonesia disarankan untuki segera melakukan regulasi seperti dapat kemudahan untuk impor kebutuhan bahan baku. Tapi jika hanya bahan baku itu tidak ada di Negara Indonesia jadi khusus industri padat karya. Contohnya menetapkan biaya/ pajak masuk impor ke Indonesia dengan biaya nol rupiah dan tidak ada lagi beban biaya apapun untuk barang dari luar negeri. Jika ada di dalam situasi seperti pandemic. maka para industri pasti akan mencari bahan baku dari negara yang tidak terdampak virus corona.

- Pemerintah Indonesia dengan memberi bantuan selama pandemi seperti uang tunai ke karywan, gojek, dan masyarakat lainnya. Hal ini sudah dilakukan di Negara inggris dan bantuan yang di berikan dapat membantu dunia usaha, karena sebagian dari upah para pekerja disubsidikan pemerintahan.

- Pemeritah memberikan insentif ke seluruh perindustrian pariwisata, dan penindustrian lainnya yang terdampak supaya parawisata dapat bertahan di masa pandemi corona. Contohmya yaitu dengan melakukan penghapusan bunga pinjaman bank untuk pengusaha yang berada di bidangkepariwisataandan menghapus pajak di bidang pariwisata atau dengan memberikan kelonggaran cicilan utang untuk melakukan penundaanpembayaran selama se tahun.

- Menurunkan harga bahan bakar minyak supaya masyarakat menengah ke bawah dapat meningkatkan daya beli dan harga gas segera diturunkan supaya biaya produksi perusahaan dapat menurun.

\section{Peran yang harus dilakukan oleh masyarakat dalam membantu menangani kasus pandemic covid - 19}

Pada saat pandemic seperti ini peran masyrakat sangat penting karena itu dapat mengurangi pasien positif covid-19. peran serta masyarakat yang efektif itu dengan cara melakukan pembatasan fisik, apalagi dengan karantina wilayah jika diterapkan. Karena dari peran masyarakat pasti akan terlibat antara ketua RT/RW, lurah, kecamatan dan tokoh masyarakat termasuk juga tokoh agama. Tokoh kepemudaan akan ikut terlibat yaitu organisasi masyarakat termasuk karang taruna.

Seluruhnya itu wajib diikutsertakan untuk menangani penyebaran virus corona. Karena semua itu harus sesuai dengan kebijakan yang mmiliki sifat dari atas ke bawah dan apalagi virus corona saat ini terus meningkat sangat tinggi dan sebab daya tampung di rumah sakit dan tenaga medis tidak memadai. Supaya adanya kesadaran warga negaraIndonesia dan warga negara indonesia mengerti bahwa virus corona ini sangat berbahaya dan perlu melakukan sosialisasi secara terus menerus ke seluruh daerah. Oleh karena itu, perlu melakukan penyuluhan agar dapat melakukan pola hidup bersih. Mengenai adanya sejumlah daerah yang melakukan karantina kewilayahan karena itulahberkomunikasi publik secara baik itu sangat penting. Makanya dibutuhkan kepiawaian dari setiap kepala daerah untuk bertanggung jawab terhadap masyarakatnya. Dengan konteks kolaboratif harus dilakukan untuk dapat memutus penyebaran virus corona. Kebijakan kolaboratif selain melibatkan pemerintah daerah dan masyarakatnya harusnya peran swasta harus ikut serta dalam memutus penyebaran virus corona agar saling bersinergi. 
Masyarakat bisa membantu melawan covid - 19 agar segera hilang dengan mematuhi protocol kesehatan dan mematuhi peraturan - peraturan yang dibuat pemerintah untuk menanggulangi masa pandemic ini. Misalnya dengan mematuhi peraturan physical social distancing, menggunakan masker saat keluar ke tempt umum, mencuci tangan dengan sabun dll. '

Selain itu masyarakat juga bisa member sumbangan berupa uang aytau tenaga. Misalnya ikut membantu penyemprotan disekitaran perumahan agar tetap steril, memberikan bantuan pada saudara / saoudati yang terdampak seperti menyumbangkan masker, uang, kebutuhan pokok dll.

\section{KESIMPULAN}

Virus corona merupakan panyakit yang sangat cepat menular dan semakin tingginya pasien positif corona maka berakibat sangat nyata seperti banyaknya perusahaan yang mem-phk(putusan hubungan kerja) karyawan dan hampir semua sektor terdampak adanya pandemic virus corona. Mulai dari sector kesehatan, sector sosial, sector ekonomi, termasuk adanya keberlangsungan dunia usaha dan tenaga kerja sehingga terjadinya pengangguran dan banyak hak-hak masyarakat yang tidak di penuhi. Adanya virus corona telah membuat situasi perekonomian di seluruh dunia termasuk Indonesia jadi memburuk.Banyak permasalahan ekonomi muncil karena pandemic ini misalnya saja banyaknya phk yang dilakukan oleh perusahaan, kontraksi PMI manufacturing, penurunan pada kinerja impor, dampak pada inflasi dan beberapa masalah ekonomi lainnya. Dampak yang ditimbulkan ssaat pandemic ini memang sangat terlihat nyata dan menimbulkan masalah yang besar bagi masyarakat maupun pemerintah dalam mencari solusi untuk mengatasi masa pandemic ini.

Selain terlihat jelas di sector ekonomi, Pengaruh covid - 19 ini juga sangat mengganggu pemenuhan hak asasi manusi bagi masyarakat. Banyaknya kehawatiran yang muncul dan hilangnya beberapa sumber penghasilan mereka merupakan salah satu hal yang sangat jelas mengganggu hak yang selama ini mereka dapatkan. Disinilah kerjasama antar pemerinath dan masyarakat harus dijunjung tinggi agar masa pandemic ini cepat berakhir dan kita dapat menjalankan kehidupan dengan normal.

\section{DAFTAR RUJUKAN}

www.kelaspintar.id/blog/inspirasi/pengaruhcovid-19-terhadap-perekonomian indonesia-4842/ (11 november 2020, 8:00 WIB )

www.kompasiana.com/keziagloria4944/5c001 a8fab12ae680757f216/perlindunganhak-asasi-manusia-ham-di-indonesia (12 november 2020, 11:00 wib) kompas.com

Jamli, Edison A.2002.Pendidkan Pancasila dan Kewarganegaraan kelas XI SMA/SMK. Jakarta: PT Bumi Aksara ( 25 november 2020 , 3:00 WIB )

Rahayu.2012.Hukum Hak Asasi Manusia ( HAM ). Semarang. Universitas Diponegoro Semarang. ( 25 november $2020,7: 00$ wib )

Vincentius Gitiyarko. 2020, Upaya dan Kebijakan Pemerintah Indonesia Menangani Pandemi COVID - 19. Kompas Pedia.

Rokom. 2020. Keberhasilan Akhiri COVID 19 Tergantung Peran Masyarakat. Sehatnegriku.kemkes.go.id

https.kemlu.go.id/hanoi/id/news/5105/langkah -dan-upaya-pemerintah-indonesiadalam-menangani-dan-menghadapicovid-19

(15 november $2020,13: 30$ wib )

https.megapolitan.kompas.com/read/2020/04/0 6/06231941/phk-massal-di-tengahpandemi-covid-19-dan-upaya pemerintah-berikan?page=all. @NursitaSari

( 7 desember 2020, 2:15 wib )

Sumber: Strategi Usulan Pemerintah Agar Perusahaan Menghindari Pemutusan 
hubungan kerja Akibat Pandemi COVID

( 7 desember 2020, 2:59 wib )

https.money.kompas.com/read/2020/04/03/210

300126/6-saran-kspikepemerintah-

untuk-cegah-phk-selama-pandemi-

corona?page $=$ all.kompas.com

( 7 desember 2020 , 3:10 wib )

Muhammad Lukhfan. 2017.Kajian Hak Asasi manusia dalam Negara Rule Of Law.Semarang.UNNES

( Untuk bahan revisi pada 15 Desember 2020 )

El-Muhtaj, Majda. 2009. Ham dalam Konstitusi Indonesia.Jakarta. Kencana.

effendi,mansyur, 2010. HAM dalam demensi/dinamika yuridis, sosial, politik, Jakarta : ghalia Indonesia

fatwa. 2000. Potret konstitusi pasca amandemen UUD 1945, Jakarta : penerbit buku kompas.

Mrzuku, suparman . 2012. Pengadilan HAM di Indonesia, melanggengkn impunity. Jakarta: penerbit erlangga. 